\title{
ANALISIS PREDIKSI KEBANGKRUTAN BERDASARKAN METODE ALTMAN Z-SCORE (STUDI KASUS PADA BANK BUMN YANG TERDAFTAR DI BEI)
}

\author{
I Komang Try Satriawan Korry \\ Made Pratiwi Dewi \\ Ni Luh Anik Puspa Ningsih
}

Fakultas Ekonomi dan Bisnis Universitas Warmadewa, Bali, Indonesia

E-mail: pratiwidewi_88@yahoo.com

\begin{abstract}
Bankruptcy Prediction Analysis Based on the Altman Z-Score Method (Case Study of State-Owned Banks Registered on the IDX). Bankruptcy phenomena can occur in every company. Based on data from the Deposit Insurance Agency (LPS), there were 90 banks liquidated since 2005 until mid-2018. Based on the phenomenon of bankruptcy that occurred, it was important for banks to be no exception for state-owned banks to recognize the symptoms of financial distress that led to bankruptcy. The purpose of this study was to determine the prediction of bankruptcy based on the Altman Z-Score method on state-owned banks listed on the Indonesia Stock Exchange (IDX). The data analysis technique used in this study is descriptive analysis techniques. The sample in this study used four state-owned banks, namely Bank Negara Indonesia, Bank Rakyat Indonesia, Bank Tabungan Nasional, and Bank Mandiri with the technique of determining saturated sampling samples and the data used were financial statements for the 2014-2017 period obtained through official IDX sites (www.idx.co.id). The results of the study show that all state-owned banks are in the gray area for the period of 2014-2017 because the value of the Z-score obtained is between 1.1 and 2.6.
\end{abstract}

Keywords: Bankruptcy Prediction; Atlman Z-Score Method.

Abstrak: Analisis Prediksi Kebangkrutan Berdasarkan Metode Altman Z-Score (Studi Kasus Pada Bank BUMN Yang Terdaftar di BEI). Fenomena kebangkrutan dapat terjadi pada setiap perusahaan. Berdasarkan data dari Lembaga Pinjamin Simpanan (LPS) tercatat sebanyak 90 bank telah dilikuidasi sejak tahun 2005 hingga pertengahan tahun 2018. Berdasarkan fenomena kebangkrutan yang terjadi, maka penting bagi bank tak terkecuali bagi Bank BUMN untuk mengenali gejala-gejala financial distress yang mengarah pada kebangkrutan. Tujuan dilaksanakan penelitian ini adalah untuk mengetahui prediksi kebangkrutan berdasarkan metode Altman Z-Score pada Bank BUMN yang terdaftar di Bursa Efek Indonesia (BEI). Teknik analisis data yang digunakan dalam penelitian ini adalah teknik analisis deskriptif. Sampel dalam penelitian ini menggunakan keempat bank BUMN yaitu Bank Negara Indonesia, Bank Rakyat Indonesia, Bank Tabungan Nasional, dan Bank Mandiri dengan teknik penentuan sampel sampling jenuh dan data yang digunakan adalah data laporan keuangan periode 2014-2017 yang diperoleh melalui sites resmi BEI (www. idx.coid). Hasil penelitian menunjuukan bahwa semua Bank BUMN berada pada kondisi grey area periode tahun 2014-2017 karena nilai Z-Score yang diperoleh berada diantara 1,1 dan 2,6.

Kata kunci: Prediksi Kebangkrutan, Metode Atlman Z-Score. 


\section{PENDAHULUAN}

Kebangkrutan merupakan kondisi perusahaan mengalami ketidakcukupan dana untuk melakukan kegiatan usaha yang dijalankan karena tidak mampu lagi menghasilkan laba. Selain itu, kebangkrutan terjadi karena perusahaan tidak mampu lagi untuk melunasi kewajiban yang dimiliki sebagai debitur hingga perusahaan terlikuidasi. Budhijama dan Nelmida (2018) menyebutkan bahwa sebelum perusahaan mengalami kebangkrutan akan diawali dengan kesulitan keuangan (financial distress). Kebangkrutan didefinisikan sebagai suatu kegagalan yaitu kegagalan ekonomi dan kegagalan bisnis. Kegagalan ekonomi berarti bahwa laba yang diperoleh perusahaan tidak mampu lagi menutupi biaya-biaya yang dimiliki. Sedangkan kegagalan bisnis yakni bisnis yang berhenti beroperasi karena perusahaan tidak mampu memenuhi kewajiban yang dimiliki (Altman: 2006).

Setiap perusahaan memiliki risiko mengalami kebangkrutan karena kesulitan keuangan dapat saja terjadi di masa depan yang mana apabila tidak diatasi secara intensif akan berakibat fatal bagi keberlangsungan hidup perusahaan. Risiko kebangkrutan akan semakin besar apabila di dalam perusahaan terjadi mismanagement atau pengelolaan sumber daya yang tidak tepat, baik sumber daya manusia ataupun pendanaan (Makhromah: 2017). Guna mengetahui munculnya krisis keuangan pada perusahaan yang akan mengancam aktivitas bisnis yang dilakukan, maka perlu dibuat suatu sistem peringatan dan penanganan yang lebih intens. Sistem peringatan dini (early self warning) untuk memprediksi adanya kesulitan keuangan yang menuju ke arah kebangkrutan adalah dengan cara prediksi kebangkrutan. Adapun indikator utama yang dijadikan dasar penilaian untuk melakukan prediksi kebangkrutan adalah laporan keuangan perusahaan yang bersangkutan. Berdasarkan laporan keuangan akan dapat dihitung sejumlah rasio keuangan yang dijadikan dasar prediksi kebangkrutan.Informasi kebangkrutan sangat penting bagi investor dan kreditor untuk mengamankan investasi kepada perusahaan tersebut (Lisdayanti, Zeini dan Anindita: 2013). Hasil analisis prediksi kebangkrutan dapat digunakan untuk meminimalisir terjadinya kerugian bagi pihak internal ataupun pihak eksternal akibat dari kebangkrutan yang dialami perusahaan, serta meramalkan kelanjutan hidup perusahaan yang bersangkutan (Anita: 2017).

Telah dikembangkan sejumlah model prediksi kesulitan keuangan dan kebangkrutan perusahaan dan salah satunya adalah metode prediksi kebangkrutan Z-Score. Z-Scoreadalah suatu alat yang digunakan untuk meramalkan tingkat kebangkrutan suatu perusahaan dengan menghitung nilai dari beberapa rasio kemudian dimasukkan dalam suatu persamaan diskriminan. Model Altman Z-Scorepertama kali diperkenalkan oleh Edward I. Altmanpada tahun 1968 yang dikembangkan untuk menentukan kecenderungan kebangkrutan perusahaan dan dapat juga digunakan sebagai ukuran dari keseluruhan kinerja keuangan (Sari: 2016). Edward Altman menggunakan Multiple Discriminant Analysis (MDA) untuk mengkombinasikan lima rasio keuangan diantaranya likuiditas, profitabilitas, leverage, solvabilitas, dan rasio aktivitas yang terintegrasi menjadi Altman Z-Score.

Fenomena kebangkrutan juga terjadi pada perbankan yang ada di Indonesia. Berdasarkan data dari Lembaga Pinjamin Simpanan (LPS) tercatat sebanyak 90 bank telah dilikuidasi sejak tahun 2005 hingga pertengahan tahun 2018. Mayoritas bank yang dilikuidasi adalah bank BPR, yakni sebanyak 89 dan satu bank umum (www.lps.go.id). Kebangkrutan yang terjadi pada bank-bank tersebut disebabkan karena manajemen perusahaan yang tidak mampu mengelola perusahaan dengan baik sehingga perencanaan dan pengelolaan perusahaan kurang maksimal (www.kompas.com).

Berikut ini data pertumbuhan laba (rugi) pada Bank BUMN yang terdaftar di Bursa Efek Indonesia (BEI) dalam empat tahun terakhir dari tahun 2014 - 2017 dapat dilihat pada Tabel 1.

Berdasarkan Tabel 1 menunjukkan bahwa perkembangan laba (rugi) pada Bank BUMN periode 2014-2017 mengalami peningkatan yang cukup baik dari tahun ke tahun. Tetapi Pertumbuhan laba pada Bank BNI dan Bank Mandiri sempat mengalami penurunan.

Berdasarkan latar belakang masalah di atas, maka permasalahan yang dapat dirumuskan dalam penelitian ini adalah:Bagaimana prediksi kebangkrutan berdasarkan metode Altman Z-Score pada Bank BUMN yang terdaftar di BEI? 
Tabel 1.

Data Perkembangan Laba (Rugi) Pada Bank BUMN periode 2014-2017 (dalam juta rupiah)

\begin{tabular}{cccccc}
\hline $\begin{array}{c}\text { Kode } \\
\text { Saham }\end{array}$ & Laba (Rugi) & \multirow{2}{*}{$\mathbf{2 0 1 4}$} & $\mathbf{2 0 1 5}$ & $\mathbf{2 0 1 6}$ & $\mathbf{2 0 1 7}$ \\
\hline \multirow{2}{*}{ BBNI } & Laba (Rugi) & 10.829 .379 & 9.140 .532 & 11.410 .196 & 13.770 .592 \\
& Pertumbuhan (\%) & & $-15.60 \%$ & $24.83 \%$ & $20.69 \%$ \\
\hline \multirow{2}{*}{ BBRI } & Laba (Rugi) & 24.253 .845 & 25.410 .788 & 26.227 .991 & 29.044 .334 \\
& Pertumbuhan (\%) & & $4,77 \%$ & $3,22 \%$ & $10,74 \%$ \\
\hline \multirow{2}{*}{ BBTN } & Laba (Rugi) & \multirow{2}{*}{1.145 .572} & 1.850 .907 & 2.618 .905 & 3.027 .466 \\
& Pertumbuhan (\%) & & $61,57 \%$ & $41,49 \%$ & $15,60 \%$ \\
\hline \multirow{2}{*}{ BMRI } & Laba (Rugi) & \multirow{2}{*}{20.654 .783} & 21.152 .398 & 14.650 .163 & 21.443 .042 \\
& Pertumbuhan (\%) & & $2,41 \%$ & $-30,74 \%$ & $46,37 \%$ \\
\hline
\end{tabular}

Sumber: www.idx.co.id, diolah untuk penelitian

Analisis Metode Altman Z-Score, Z-Score adalah skor yang ditentukan dari hitungan standar kali rasio-rasio keuangan yang menunjukkan tingkat kemungkinan kebangkrutan perusahaan. Formula Z-Score untuk memprediksi kebangkrutan dari Altman merupakan sebuah multivariate formula yang digunakan untuk mengukur kesehatan finansial dari sebuah perusahaan.Altman merupakan orang petama yang menggunakan teknik Multiple Discriminan Analysis (MDA) pada tahun 1968, teknik analisis diskriminan ini merupakan teknik statistik yang mengidentifikasi beberapa rasio keuangan yang dianggap mempengaruhi suatu kejadian. Menemukan lima jenis rasio keuangan yang dapat dikombinasikan untuk melihat perbedaan antara perusahaan yang bangkrut dan yang tidak bangkrut.

Penggunaan model Altman Z-Score sebagai salah satu pengukuran kinerja kebangkrutan tidak bersifat tetap ataupun stagman melainkan berkembang dari waktu ke waktu, yang mana pengujian dan penemuan model terus diperluas oleh Altman hingga dapat diterapkan pada semua perusahaan baik perusahaan manufaktur maupun perusahaan non maknufaktur khusunya perusahaan jasa (Oktarina: 2017). Altman melakukan modifikasi terhadap model prediksi kebangkrutan untuk meminimalisir efek industri karena keberadaan variabel perputaran aset yaitu dengan mengeleminasi variabel X5 (Sales to Total Assets) . Dengan model yang telah modifikasi, model Altman Z-Score dapat diterapkan pada semua perusahaan baik perusahaan manufaktur dan nonmanufaktur (Altman: 2000). Rumus $Z$-Score Modifikasi adalah sebagai berikut $Z=6,56 X_{1}+3,26 X_{2}+6,72 X_{3}+1,05 X_{4}$

Sumber: Altman, 2006

Model ini terjadi banyak perubahaan seperti dihilangkannya X5 karena pada perusahaan jasa tidak mengenal yang namanya sale dan X 5 ini menggambarkan perputaran asset dan ini dianggap tidak terlalu berperpengaruh terhadap laba dari perussahaan jasa, ini adalah model yang khusus untuk perusahaan di luar manufaktur, seperti perusahaan jasa (Andita: 2018).Adapun nilai cut off yang digunakan adalah:

$\mathrm{Z}<1,1 \quad$ :Berada dalam zona kebangkrutan

$1,1<\mathrm{Z}<2,6 \quad$ : Grey area atau daerah kelabu $Z>2,6 \quad$ : Sehat/ tidak bangkrut

Keterangan:

$\mathrm{X}_{1}$ : Net Working Capital to Total Assets. Merupakan rasio yang menunjukkan kemampuan perusahaan untuk menghasilkan modal kerja bersih dari keseluruhan total aktiva yang dimiliki perusahaan. Rasio ini dihitung dengan membagi modal kerja bersih dengan total aktiva.

$\mathrm{X}_{2}$ : Retained Earning to Total Assets. Digunakan untuk mengukur profitabilitas kumulatif. Rasio ini mengukur akumulasi 
laba selama perusahaan beroperasi. Umur perusahaan berpengaruh terhadap rasio tersebut karena semakin lama perusahaan beroperasi memungkinkan untuk memperlancar akumulasi laba ditahan. Umur perusahaan dapat menyebabkan perusahaan yang masih relative muda pada umumnya akan menunjukkan hasil rasio yang rendah, kecuali yang labanya sangat besar pada masa awal berdirinya.

$\mathrm{X}_{3}$ : Earning Before Interest and Taxes to Total Assets. Merupakan rasio yang mengukur kemampuan modal yang diinvestasikan dalam keseluruhan aktiva untuk menghasilkan keuntungan bagi semua investor termasuk pemegang saham. Rasio ini berfungsi sebagai alat pengaman jika perusahaan mengalami kegagalan keuangan, oleh karena itu rasio ini dianggap paling berkontribusi dalam menilai kelangsungan hidup perusahaan.

$\mathrm{X}_{4}$ : Book Value of Equity to Liabilities. Digunakan untuk mengukur seberapa banyak aktiva perusahaan dapat turun nilainya sebelum jumlah utang lebih besar daripada aktivanya dan perusahaan menjadi pailit. Modal yang dimaksud adalah gabungan nilai pasar dari modal biasa dan saham preferen, sedangkan hutang mencakup hutang lancar dan hutang jangka panjang.Berdasarkan latar belakang

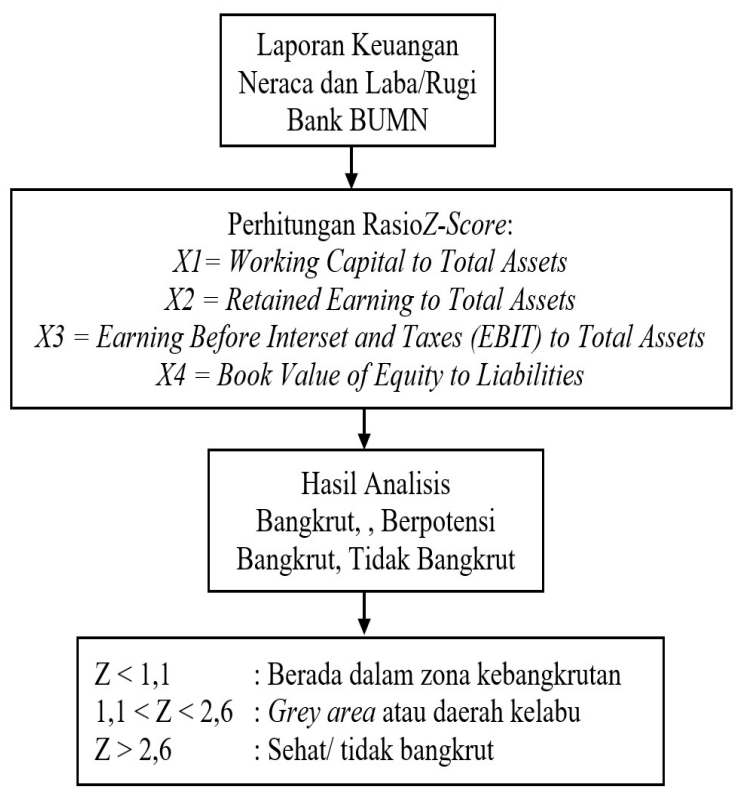

Sumber: Data diolah

Gambar 1. Kerangka Pemikiran dan Konseptual masalah serta teori dan hasil penelitian terdahulu dapat digambarkan kerangka pemikiran dan konseptual sebagai berikut:

\section{METODE PENELITIAN}

Penelitian ini dilakukan di Bursa Efek Indonesia pada perusahaan sektor perbankan yaitu Bank BUMN melalui website: www.idx. co.id . Objek penelitian adalah Rasio Z-score yaitu Working capital to total assets, Retained earning to total assets, earning before interest and taxes (EBIT) to total assets, Book value of equity to liabilities dari Bank BUMN yang terdaftar di Bursa Efek Indonesia.

Populasi dalam penelitian ini adalah semua Bank BUMN yang terdaftar di BEI yang berjumlah 4 bank yaitu Bank Negara Indonesia, Bank Rakyat Indonesia, Bank Tabungan Nasional, dan Bank Mandiri. Dalam penelitian ini, peneliti menggunakan sampling jenuh. Sampling jenuh adalah teknik penentuan sampel bila semua anggota populasi digunakan sebagai sampel. Penggunaan teknik ini dilakukan jika populasi berjumlah relatif kecil atau peneiti ingin membuat generalisasi dengan tingkat kesalahan yang sangat kecil (Sugiyono, 2017: 85)

Variabel yang dipergunakan dalam penelitian ini, yaitu: $Z$-Score yaitu skor yang ditentukan dari hitungan standar kali rasio-rasio keuangan yang menunjukkan tingkat kemungkinan kebangkrutan pada Bank BUMN. Working Capital to Assets Ratio $\left(\mathrm{X}_{1}\right)$ yaitu rasioa menunjukkan kemampuan Bank BUMN dalam menghasilkan modal kerja bersih dari keseluruhaan total aktiva yang dimiliki. Retained Earning to Total Assets ( $\mathrm{X}_{2}$ ) yaitu rasio yang menunjukkan kemampuan Bank BUMN untuk menghasilkan laba ditahan dari total aktiva selama masa operasi Bank BUMN. Earnings Before Taxes To Total Assets $\left(\mathrm{X}_{3}\right)$ yaitu rasio yang digunakan untuk mengukur kemampuan Bank BUMN dalam menghasilkan laba dari aktiva yang digunakan. Book Value of Equity to Liabilities $\left(\mathrm{X}_{4}\right)$ yaitu rasio yang digunakan untuk mengukur kemampuan Bank BUMN dalam memenuhi kewajiban-kewajiban dari modal sendiri.

Penelitian ini menggunakan data sekunder. Data sekunder adalah data yang diperoleh melalui pihak lain, tidak langsung diperoleh oleh peneliti dari subjek penelitiannya (Azwar: 2013). Data yang digunakan dalam 
peneitian ini yaitu laporan keuangan tahunan perusahaan yang diambil dan dikutip dari data-data yang sudah ada kemudian diolah dan dianalisis. Semua data yang digunakan dalam penelitian ini diperoleh dari Bursa Efek Indonesia melalui www.idx.co.id.

Teknik analisis data yang digunakan dalam penelitian ini adalah teknik analisis deskriptif. Teknik analisis deskriptif menurut Sugiyono (2017: 35) adalah penelitian yang dilakukanuntukmengetahuikeberadaanvariabel mandiri, baik hanya pada satu variabel atau lebih (variabel yang berdiri sendiri) tanpa membuat perbandingan dan mencari hubungan variabel itu dengan variabel yang lain. Alat analisis yang digunakan dalam penelitian ini adalah model Altman Z-Score modifikasi untuk menganalisis potensi kebangkrutan pada Bank BUMN. Berikut rumus untuk menghitung nilai Z-Score:

$$
\mathrm{Z}=6,56 \mathrm{X}_{1}+3,26 \mathrm{X}_{2}+6,72 \mathrm{X}_{3}+1,05 \mathrm{X}_{4}
$$

Net Working Capital to Total Assets $\left(\mathrm{X}_{1}\right)$

$$
\mathrm{X}_{1}=\frac{\text { Modal Kerja }}{\text { Total Aktiva }}
$$

Retained Earning to Total Assets $\left(\mathrm{X}_{2}\right)$

$$
\mathrm{X}_{2}=\frac{\text { Laba yang Ditahan }}{\text { Total Aktiva }}
$$

Earning Before Taxes (EBIT) to Total Assets $\left(\mathrm{X}_{3}\right)$

$$
\mathrm{X} 3=\frac{\text { EBIT }}{\text { Total Aktiva }}
$$

Book Value of Equity to Liabilities $\left(\mathrm{X}_{4}\right)$

$$
\mathrm{X}_{4}=\frac{\text { Total ekuitas }}{\text { Total Hutang }}
$$

Sumber: Altman, 2006

Adapun nilai cut off yang digunakan adalah:
$\mathrm{Z}<1,1 \quad$ : Berada dalam zona kebangkrutan $1,1<Z<2,6 \quad$ : Grey area atau daerah kelabu $\mathrm{Z}>2,6 \quad$ : Sehat/ tidak bangkrut

\section{HASIL DAN PEMBAHASAN}

Nilai Z-Score dan diklasifikasikan ke dalam keadaan aman, grey area atau bangkrut pada setiap Bank BUMN, maka yang dilakukan adalah menghitung rasio keuangan Bank BUMN dengan rumus Altman Z-Score modifikasi. Berikut ini perhitungan dan analisis rasio keempat variabel berdasarkan laporan keuangan publikasi Bank BUMN tahun 20142017.Net Working Capital to Total Assets $\left(\mathrm{X}_{1}\right)$. Hasil perhitungan modal kerja bersih dari masing-masing Bank BUMN dari tahun 20142017 dapat dilihat pada tabel 2.

Jumlah modal kerja bersih dari masingmasing Bank BUMN, maka selanjutnya adalah menghitung rasio Net working capital to total assets $\left(\mathrm{X}_{1}\right)$ Hasil perhitungan rasio net working capital to total assets (X1) dapat dilihat pada Tabel 3. Hasil dari Tabel 3 dapat diketahui perhitungan modal kerja bersih terhadap total aset yang dimiliki oleh masing-masing Bank BUMN.Hasil perhitungan $\mathrm{X}_{1}$ terendah dimiliki oleh Bank BRI yaitu pada tahun 2014 sebesar $(0,116)$ atau $(11,6 \%)$ yang artinya, setiap penggunaan Rp 1 aktiva yang dimiliki oleh Bank BRI akan menghasilkan modal kerja bersih sebesar Rp 0,116 dan X1 tertinggi dimiliki oleh Bank BTN yaitu pada tahun 2017 sebesar 0,195 atau 19,5\% yang memiliki arti, setiap penggunaan Rp 1 aktiva yang dimiliki oleh Bank BTN akan menghasilkan modal kerja bersih sebesar Rp 0,195.

Selanjutnya menghitungRetained Earning to Total Assets $\left(\mathrm{X}_{2}\right)$. Hasil perhitungan retained earning to total assets (X2) dapat dilihat pada

Tabel 2.

\section{Data Modal Kerja BersihPada Bank BUMN Periode}

\begin{tabular}{rlrrrr}
\hline No. & Nama Bank & $\mathbf{2 0 1 4}$ & \multicolumn{2}{c}{ Modal Kerja Bersih } \\
\hline 1. & Bank BRI & 93.103 .836 & 103.744 .900 & 141.788 .307 & 158.994 .400 \\
2. & Bank BNI & 76.628 .814 & 83.717 .131 & 98.634 .483 & 109.076 .187 \\
3. & Bank BTN & 22.546 .488 & 21.696 .820 & 40.442 .432 & 50.910 .937 \\
4. & Bank Mandiri & 155.009 .414 & 167.457 .648 & 199.463 .973 & 215.364 .287 \\
\hline
\end{tabular}

Sumber : data diolah 
Tabel 3.

Perhitungan Rasio Net Working Capital to Total Assets (X1) Bank BUMN Periode 2014-2017

\begin{tabular}{llllll}
\hline No & Nama Bank & $\mathbf{2 0 1 4}$ & $\mathbf{2 0 1 5}$ & $\mathbf{2 0 1 6}$ & $\mathbf{2 0 1 7}$ \\
\hline 1. & Bank BRI & 0,116 & 0,118 & 0,141 & 0,141 \\
2. & Bank BNI & 0,184 & 0,165 & 0,163 & 0,148 \\
3. & Bank BTN & 0,156 & 0,126 & 0,189 & 0,195 \\
4. & Bank Mandiri & 0,181 & 0,184 & 0,192 & 0,191 \\
\hline
\end{tabular}

Sumber : data diolah

Tabel 4.

Perhitungan Rasio Retained Earning to Total Assets (X2) Bank BUMN Periode 2014-2017

\begin{tabular}{llllll}
\hline No & Nama Bank & $\mathbf{2 0 1 4}$ & $\mathbf{2 0 1 5}$ & $\mathbf{2 0 1 6}$ & $\mathbf{2 0 1 7}$ \\
\hline 1. & Bank BRI & 0,111 & 0,122 & 0,125 & 0,128 \\
2. & Bank BNI & 0,084 & 0,082 & 0,084 & 0,082 \\
3. & Bank BTN & 0,035 & 0,039 & 0,042 & 0,044 \\
4. & Bank Mandiri & 0,087 & 0,098 & 0,093 & 0,099 \\
\hline
\end{tabular}

Sumber : data diolah

Tabel 4.Berdasarkan Tabel 4 menunjukkan hasil perhitungan laba ditahan terhadap total aset pada masing-masing Bank BUMN mengalami fluktuasi setiap tahunnya.

Nilai rasio X2 yang paling rendah dimiliki oleh Bank BTN yaitu pada tahun 2014 sebesar 0,035 atau sebesar 3,5\% yang artinya, setiap penggunaan Rp 1 aktiva yang dimiliki oleh oleh Bank BTN akan menghasilkan retained earnings sebesar Rp 0,035. Nilai rasio X2 terbesar dimiliki oleh Bank BRI yaitu pada tahun 2017 sebesar 0,128 atau sebesar $12,8 \%$ yang artinya, setiap penggunaan Rp 1 aktiva yang dimiliki oleh Bank BRI akan menghasilkan retained earnings sebesar Rp 0,128.

Menghitung Earnings Before Taxes To Total Assets $\left(\mathrm{X}_{3}\right)$. Hasil perhitungan rasio earning before taxes (EBIT) and interest to total assets (X3) dapat dilihat pada Tabel 5.Hasil perhitungan rasio $\mathrm{X}_{3}$ dapat dilihat di Tabel 5 yaitu earnings before tax to total assets pada Bank BUMN mengalami fluktuasi setiap tahunnya. Rasio $\mathrm{X}_{3}$ terendah dimiliki oleh Bank BTN yaitu pada tahun 2014 sebesar 0,011 atau 1,1\% yang artinya, setiap penggunaan Rp 1 aktiva yang dimiliki oleh Bank BTN akan menghasilkan EBIT sebesar Rp 0,011. Nilai rasio $X_{3}$ terbesar dimiliki oleh Bank BRI yaitu pada tahun 2014 sebesar 0,035 atau $3,5 \%$ yang artinya, setiap penggunaan Rp 1 aktiva yang dimiliki oleh Bank BRI akan menghasilkan EBIT sebesar Rp 0,035.
Menghitung Book Value of Equity to Liabilities $\left(\mathrm{X}_{4}\right)$.Tabel 6 merupakan hasil perhitungan dari book value of equity to liabilities $\left(\mathrm{X}_{4}\right)$ pada masing-masing Bank BUMN dari tahun 2014-2017.Berdasarkan hasil perhitungan $\mathrm{X}_{4}$ pada Tabel 6 nilai pasar ekuitas terhadap nilai total utang ada menunjukkan hasil fluktuatif dan ada yang meningkat secara konsisten. Nilai $\mathrm{X}_{4}$ yang paling rendah dimiliki oleh Bank BTN yaitu pada tahun 2015 sebesar 0,088 atau 8,8\% yang artinya, setiap $\mathrm{Rp} 1$ utang yang dimiliki oleh Bank BTN dicakup sebesar Rp 0,088 oleh nilai buku ekuitas yang dimiliki. Nilai rasio $\mathrm{X}_{4}$ terbesar yaitu dimiliki oleh Bank Mandiri pada tahun 2017 sebesar 0,191 atau $19,1 \%$ yang artinya, setiap Rp 1 utang yang dimiliki oleh Bank Mandiri dicakup sebesar Rp 0,191 oleh nilai buku ekuitas yang dimiliki bank tersebut.

Menghitung nilai Z-Score pada masingmasing Bank BUMN. Setelah melakukan perhitungan terhadap masing-masing rasio pada Bank BUMN, langkah seanjutnya adalah menghitung nilai $Z$-Score untuk masingmasing Bank BUMN dengan memasukkan hasil perhitungan rasio tersebut kedalam model persamaan Z-Score modifikasi dengan mengalikan hasil rasio Tabel 6 dengan nilai koefisien dari masing-masing variabel. Rumus $Z$-Score yang digunakan adalah sebagai berikut:

$Z=6,56 X_{1}+3,26 X_{2}+6,72 X_{3}+1,05 X_{4}$

Sumber: Altman, 2000 
Tabel 5.

Perhitungan Rasio Earnings Before Taxes To Total Assets $\left(\mathrm{X}_{3}\right)$ Bank BUMN Periode 2014-2017

\begin{tabular}{llcccc}
\hline No & Nama Bank & $\mathbf{2 0 1 4}$ & $\mathbf{2 0 1 5}$ & $\mathbf{2 0 1 6}$ & $\mathbf{2 0 1 7}$ \\
\hline 1. & Bank BRI & 0,035 & 0,034 & 0,034 & 0,033 \\
2. & Bank BNI & 0,033 & 0,022 & 0,024 & 0,023 \\
3. & Bank BTN & 0,011 & 0,015 & 0,016 & 0,015 \\
4. & Bank Mandiri & 0,030 & 0,029 & 0,018 & 0,024 \\
\hline
\end{tabular}

Sumber : data diolah

Tabel 6.

Perhitungan Rasio Book Value of Equity to Liabilities $\left(\mathbf{X}_{4}\right)$ Bank BUMN Periode 2014-2017

\begin{tabular}{llcccc}
\hline No & Nama Bank & $\mathbf{2 0 1 4}$ & $\mathbf{2 0 1 5}$ & $\mathbf{2 0 1 6}$ & $\mathbf{2 0 1 7}$ \\
\hline 1. & Bank BRI & 0,139 & 0,148 & 0,171 & 0,175 \\
2. & Bank BNI & 0,179 & 0,190 & 0,181 & 0,173 \\
3. & Bank BTN & 0,093 & 0,088 & 0,090 & 0,090 \\
4. & Bank Mandiri & 0,140 & 0,162 & 0,186 & 0,191 \\
\hline
\end{tabular}

Sumber : data diolah

Adapun nilai cut off yang digunakan adalah:v

$\mathrm{Z}<1,1 \quad$ : Berada dalam zona kebangkrutan

$1,11<\mathrm{Z}<2,6 \quad$ : Grey area atau daerah kelabu

$Z>2,6 \quad:$ Sehat/ tidak bangkrut

$Z=6,56 X_{1}+3,26 X_{2}+6,72 X_{3}+1,05 X_{4}$

Berikut tabel 7 sampai dengan tabel 9 merupakan hasil perhitungan Z-Score pada masing-masing Bank BUMN.Berdasarkan hasil perhitungan $Z$-Scorepada masing-masing Bank BUMN di tahun 2014, menunjukkan bahwa nilai Z-Scorekeseluruhan pada Bank BUMN di 2014 berada di antara 1,1 dan 2,6 $(1,1<Z$-Score $<$ $2,6)$. Artinya seluruh Bank BUMN berada pada kategori grey area. Untuk tahun 2014 nilai $Z$-Score terendah dimiliki oleh Bank BTN yaitu sebesar 1,644 diikuti oleh Bank BRI dengan nilai $Z$-Scoresebesar 1,750 . Kemudian nilai $Z$-Score terbesar kedua dimiliki oleh Bank Mandiri yaitu sebesar 2,024 dan nilai $Z$-Score tertinggi dimiliki oleh Bank BNI dengan nilai sebesar 2,091.

Hasil Analisis Model Altman Z-Score Tahun 2015

Berdasarkan tabel 8 menunjukkan bahwa hasil perhitungan Z-ScoreBank BNI dan Bank BTN mengalami penurunan dari tahun sebelumnya. Sedangkan Bank BRI dan Bank Mandiri memiliki nilai Z-Score yang meningkan dari tahun sebelumnya. Akan tetapi berdasarkan kriteria penilaian, bahwa nilai Z-Score dari keempat Bank BUMN pada tahun 2015 yang telah dihitung mengindikasikan Bank BUMN masih berada pada zona grey area karena nilai Z-Scoreyang diperoleh berada diantara 1,1 dan 2,6 $(1,1<Z$-Score $<2,6)$. Adapun nilai Z-Score terendah dimiliki oleh Bank BTN yaitu sebesar 1,457 , nilai Z-Score terendah kedua dimiliki oleh Bank BRI yaitu sebesar 1,870, kemudian diikuti oleh Bank BNI dengan nilai Z-Scoresebesar 2,016 dan nilai Z-Score 2,153 pada Bank Mandiri.

Hasil Analisis Model Altman Z-Score Tahun 2016. Berdasarkan hasil perhitungan Z-Scoredi atas menunjukkan nilai Z-Score pada Bank BRI, Bank BNI dan Bank BTN mengalami peningkatan dari tahun sebelumnya dan pada Bank Mandiri nilai Z-Score yang diperoleh menurun dibandingkan dengan tahun sebelumnya. Hasil dari analisis berdasarkan model Altman Z-Score modifikasi pada tahun 2016 mengindikasikan bahwa keempat Bank BUMN berada pada zona grey area karena nilai Z-Score yang diperoleh berada diantara 1,1 dan 2,6 (1,1<Z-Score $<2,6$. Nilai Z-Score terendah dimiliki oleh Bank BTN dengan nilai Z-Score sebesar 1,752, Z-Scoreterendah kedua dimiliki oleh Bank BRI yaitu sebesar 2,015. Kemudian nilai Z-Score terbesar kedua dimiliki oleh Bank Mandiri dengan nilai Z-Score sebesar 2,046 dan nilai Z-Score terbesar dimiliki oleh Bank BNI 
Tabel 7.

Hasil Analisis Dengan Metode Z-Score Modifikasi

Pada Bank BUMN Tahun 2014

\begin{tabular}{clccccc}
\hline No & Nama Bank & $\mathbf{6 , 5 6} \mathbf{X}_{\mathbf{1}}$ & $\mathbf{3 , 2 6} \mathbf{X}_{\mathbf{2}}$ & $\mathbf{6 , 7 2} \mathbf{X}_{\mathbf{3}}$ & $\mathbf{1 , 0 5} \mathbf{X}_{\mathbf{4}}$ & Z-Score \\
\hline 1. & Bank BRI & 0,966 & 0,400 & 0,238 & 0,146 & 1,750 \\
2. & Bank BNI & 1,383 & 0,305 & 0,215 & 0,188 & 2,091 \\
3. & Bank BTN & 1,345 & 0,128 & 0,073 & 0,097 & 1,644 \\
4. & Bank Mandiri & 1,360 & 0,313 & 0,204 & 0,147 & 2,024 \\
\hline
\end{tabular}

Sumber : data diolah

Tabel 8.

Hasil Analisis Dengan Metode Z-Score Modifikasi

Pada Bank BUMN Tahun 2015

\begin{tabular}{rlccccc}
\hline No & Nama Bank & $\mathbf{6 , 5 6} \mathbf{X}_{\mathbf{1}}$ & $\mathbf{3 , 2 6} \mathbf{X}_{\mathbf{2}}$ & $\mathbf{6 , 7 2} \mathbf{X}_{\mathbf{3}}$ & $\mathbf{1 , 0 5} \mathbf{X}_{\mathbf{4}}$ & Z-Score \\
\hline 1. & Bank BRI & 1,040 & 0,440 & 0,233 & 0,155 & 1,870 \\
2. & Bank BNI & 1,370 & 0,296 & 0,151 & 0,199 & 2,016 \\
3. & Bank BTN & 1,123 & 0,142 & 0,099 & 0,092 & 1,457 \\
4. & Bank Mandiri & 1,433 & 0,355 & 0,194 & 0,170 & 2,153 \\
\hline
\end{tabular}

Sumber : data diolah

Tabel 9.

Hasil Analisis Dengan Metode Z-Score Modifikasi

\begin{tabular}{clccccc}
\hline No & Nama Bank & $\mathbf{6 , 5 6} \mathbf{X}_{\mathbf{1}}$ & $\mathbf{3 , 2 6} \mathbf{X}_{\mathbf{2}}$ & $\mathbf{6 , 7 2} \mathbf{X}_{\mathbf{3}}$ & $\mathbf{1 , 0 5} \mathbf{X}_{\mathbf{4}}$ & Z-Score \\
\hline 1. & Bank BRI & 1,156 & 0,452 & 0,230 & 0,180 & 2,015 \\
2. & Bank BNI & 1,425 & 0,305 & 0,159 & 0,190 & 2,080 \\
3. & Bank BTN & 1,392 & 0,152 & 0,105 & 0,103 & 1,752 \\
4. & Bank Mandiri & 1,393 & 0,338 & 0,121 & 0,195 & 2,046 \\
\hline
\end{tabular}

Sumber : data diolah

yaitu sebesar 2,080.

Hasil Analisis Model Altman Z-Score Tahun 2017 Data pada tabel 10 menunjukkan bahwa nilai Z-Score yang dimiliki Bank BNI mengalami penurunan dibandinkan tahun sebelumnya dan tiga Bank BUMN lainnya yaitu Bank BRI, Bank BTN, dan Bank Mandiri memiliki nilai Z-Score yang meningkat dari tahun sebelumnya. Nilai Z-Score seluruh Bank BUMN memiliki hasil yang sama dengan tahun sebelumnya yaitu seluruh Bank BUMN berada pada kategori grey area. Hasil ini diperoleh berdasarkan hasil perhitungan $\mathrm{Z}$-Score pada tahun 2017 berada diantara 1,1 dan 2,6 (1,1 $<$ Z-Score $<2,6)$. Adapun nilai Z-Score terendah dimiliki oleh Bank BTN yaitu sebesar 1,833, diikuti dengan Bank BRI dengan nilai Z-Scoresebesar 1,962. Selanjtunya nilai Z-Scoreterbesar kedua dimiliki oleh Bank BNI yaitu sebesar 2,009 dan nilai Z-Score terbesar dimiliki oleh Bank Mandiri yaitu 2,186.

Setelah melakukan perhitungan untuk menilai kondisi perusahaan dengan menghitung rasio-rasio keuangan dalam model Z-Score yang terdiri dari net working capital to total assets $\left(\mathrm{X}_{1}\right)$, retained earning to total assets $\left(\mathrm{X}_{2}\right)$, earning before interest and

taxes (EBIT) and interest to total assets $\left(\mathrm{X}_{3}\right)$, dan Book Value of Equity to Liabilities $\left(\mathrm{X}_{4}\right)$ kemudian menghitung nilai Z-Score untuk masing-masing Bank BUMN, dan melakukan analisis nilai Z-Score. Selanjutnya, dilakukan pembahasan yang memuat tentang hasil penelitian dan analisis data. Berikut ini adalah hasil penilaian dari pembahasan pada Bank BUMN selama empat tahun.

Berdasarkan Tabel 11 dapat dilihat bahwa kondisi Bank BUMN berada pada zona grey area atau kondisi keuangan yang tidak dapat ditentukkan. Daerah grey area menunjukkan bahwa pertumbuhan yang dialami Bank BUMN dapat meningkat ataupun menurun. Hasil keseluruhan yang mengindikasikan Bank BUMN berada di zona grey area karena hasil perhitungan rasio $\mathrm{X}_{2}$ (retained earning to total assets) dan $\mathrm{X}_{3}$ (EBIT to total assets) yang sangat rendah. Faktor penyebab rendahnya rasio $\mathrm{X}_{2}$ dan $\mathrm{X}_{3}$ adalah karena tingginya nilai total aset yang dimiliki oleh masing-masing Bank BUMN yang tidak diimbangi dengan nilai retained earnings 
Tabel 10.

Hasil Analisis Dengan Metode $Z$-Score Modifikasi Pada Bank BUMN Tahun 2017

\begin{tabular}{clccccc}
\hline No & Nama Bank & $\mathbf{6 , 5 6} \mathbf{X}_{\mathbf{1}}$ & $\mathbf{3 , 2 6} \mathbf{X}_{\mathbf{2}}$ & $\mathbf{6 , 7 2} \mathbf{X}_{\mathbf{3}}$ & $\mathbf{1 , 0 5} \mathbf{X}_{\mathbf{4}}$ & Z-Score \\
\hline 1. & Bank BRI & 1,097 & 0,462 & 0,219 & 0,183 & 1,962 \\
2. & Bank BNI & 1,372 & 0,297 & 0,158 & 0,181 & 2,009 \\
3. & Bank BTN & 1,478 & 0,159 & 0,100 & 0,095 & 1,833 \\
4. & Bank Mandiri & 1,464 & 0,358 & 0,162 & 0,201 & 2,186 \\
\hline
\end{tabular}

Sumber : data diolah

Tabel 11.

Hasil Penilaian Z-Score Pada Bank BUMN Periode 2014-2017

\begin{tabular}{clcccc}
\hline \multirow{2}{*}{ No. } & \multirow{2}{*}{ Nama Bank } & \multicolumn{4}{c}{ Z-Score } \\
\cline { 3 - 6 } & & $\mathbf{2 0 1 4}$ & $\mathbf{2 0 1 5}$ & $\mathbf{2 0 1 6}$ & $\mathbf{2 0 1 7}$ \\
\hline 1. & Bank BRI & $1,750(\mathrm{ga})$ & $1,870(\mathrm{ga})$ & $2,015(\mathrm{ga})$ & $1,962(\mathrm{ga})$ \\
2. & Bank BNI & $2,091(\mathrm{ga})$ & $2,080(\mathrm{ga})$ & $2,080(\mathrm{ga})$ & $2,009(\mathrm{ga})$ \\
3. & Bank BTN & $1,644(\mathrm{ga})$ & $1,457(\mathrm{ga})$ & $1,752(\mathrm{ga})$ & $1,833(\mathrm{ga})$ \\
4. & Bank Mandiri & $2,024(\mathrm{ga})$ & $2,153(\mathrm{ga})$ & $2,046(\mathrm{ga})$ & $2,186(\mathrm{ga})$ \\
\hline
\end{tabular}

Sumber : data diolah

*ga: grey area

dan nilai EBIT atau laba sebelum bunga dan pajak yang yang diperoleh, atau dengan kata lain nilai retained earnings dan EBIT yang tidak terlalu besar harus dibandingkan dengan total aset yang sangat tinggi sehingga menghasilkan nilai rasio $\mathrm{X}_{2}$ dan $\mathrm{X}_{3}$ yang rendah. Selain itu, total hutang yang dimiliki oleh Bank BUMN yang meningkat setiap tahun dan tergolong sangat besar mengakibatkan jumlah modal kerja bersih yang dihasilkan tidak terlalu besar sehingga hal tersebut berpengaruh terhadap nilai rasio X1 (net working capitat to total assets).

Nilai rasio yang diperoleh tentunya sangat bepengaruh terhadap perhitungan nilai Z-Score yang dilakukan. Apabila nilai rasio yang diperoleh tinggi maka akan menghasilkan nilai Z-Score yang tinggi dan sebaliknya apabila nilai rasio yang diperoleh rendah maka hasil perhitungan Z-Score juga akan rendah.

\section{SIMPULAN DAN SARAN}

Berdasarkan hasil analisis dan pembahasan pada bab V, maka dapat disimpulkan bahwa hasil analisis Z-Score untuk kinerja keuangan pada Bank BUMN yang terdaftar di Bursa Efek Indonesia (BEI) periode 2014-2017 diperoleh nilai $Z$-Score berada diantara 1,1 dan $2,6(1,1$ $<Z$-Score Bank BUMN $<2,6)$. Berdasarkan kriteria penilaian Z-Score, Bank BUMN dapat dikategorikan kedalam kondisi keuangan yang tidak dapat ditentukan atau berada di zona grey area. Bagi pihak manajemen masing-masing Bank BUMN harus mampu meningkatkan kinerja keuangan yang dimiliki melihat hasil perhitungan Z-Score yang berada pada kondisi yang tidak dapat ditentukan atau berada di zona grey area. Perbaikan kinerja menurut metode Altman $Z$-Score, manajemen bank harus meningkatkan rasio $\mathrm{X}_{2}$ (retained earning to total assets) dan rasio $\mathrm{X}_{3}$ (EBIT and interest to total assets) dengan cara meningkatkan laba ditahan dan laba bersih yang dimiliki oleh masing-masing Bank BUMN.

Penelitian selanjutnya, diharapkan menggunakan jangka waktu penelitian lebih dari 4 tahun agar dapat memperoleh hasil yang lebih objektif. Selain itu agar peneliti selanjutnya menambah alat analisis sehingga dapat dijadikan perbandingan dan hasil penelitian menjadi lebih baik dan optimal.

\section{REFERENSI}

Alifiana dan Arumsari. 2017. "Analisis Kinerja Bank Badan Usaha Milik Negara Berdasarkan Metode Altman dan Return Saham Studi pada PT. Bank Negara Indonesia (Persero) Tbk". Jurnal Prosiding SNATIF Ke-4, 551-554. Universitas Muria Kudus.

Andita, I Putu Mahendra. (2018). "Analisis Prediksi Kebangkrutan dan Kinerja Keuan- 
gan Pada Beberapa Bank Umum yang Terdaftar di Bursa Efek Berdasarkan Metode Z-Score dan Likuiditas, Profitabilitas, Laverage". Skripi. Fakultas Ekonomi Universitas Warmadewa.

Anita, Sherly Maria. 2017. "Analisis Prediksi Kebangkrutan Studi Kasus di Perusahaan Jasa Sub Sektor Restoran, Hotel, dan Pariwisata tahun 2011-2015”. Skripsi Tidak Dipublikasikan. Univeritas Sanata Dharma Yogyakarta.

Azwar. 2013. Metode Penelitian. Yogyakarta. Pustaka Pelajar.

Budhijana, Bambang dan Nelmida. 2018. "Analisis Risiko Kebangkrutan Pada Perusahaan Bank Umum Swasta Nasional yang Terdaftar di Bursa Efek Indonesia. STIE Indonesia Banking School". Jurnal Akuntansi Keuangan dan Bisnis, 11 (1), 99-109.

Febrianto, Wahyu. 2018. “Analisis Prediksi Financial Distress Menggunakan Metode Z-Score (Altman) dan Springate Pada Bank Umum BUMN yang Terdaftar di BEI Tahun 2010-2016". Jurnal Simki-Economic, 1(3). Universitas Nusantara PGRI Kediri.

Hanafi dan Halim. (2018). Analisis Laporan Keuangan, Edisi Kelima. Yogyakarta: UPP STIM YKPN.

Harmono. (2014). Manajemen Keuangan Berbasis Balanced Scorecard Pendekatan Teori, Kasus, dan Riset Bisnis. Jakarta: PT. Bumi Aksara.

Hutagalung, Y. N. 2018. "Analisis Kemungkinan Kebangkrutan Dengan Metode Altman Pada Perusahaan Makanan dan Minuman Serta Perbankan yang Terdaftar di Bursa Efek Indonesia". Skripsi Tidak Dipublikasikan. Universitas Sumatera Utara. Medan.

Kadim dan Sunardi. 2018. "Analisis Altman Z-Score Untuk Memprediksi Kebangkrutan Pada Bank Pemerintah (BUMN) di Indonesia Tahun 2012-2016". Jurnal Sekuritas (Saham, Ekonomi Keuangan dan Investasi), 1(3), 142-156. Universitas Pamulang.

Kasmir. (2017). Analisis Laporan Keuangan. Jakarta: PT. RajaGrafindo Persada.
Lisdayanti, Zeina, Anindita. 2013. "Analisis Potensi Kebangkrutan Bank yang Terdaftar di BEI Tahun 2012 Dengan Menggunakan Model Altman Z-Score". Jurnal Proceding PESAT (Psikologi, Ekonomi, Sastra, Arsitektur, \& Teknik Sipil), 5, 414-421. Universitas Gunadarma.

Makromah, Lisa Aini. 2017. "Analisis Prediksi Kebangkrutan Perusahaan Menggunakan Model Springate dan Altman Z-Score (Studi Empiris pada Perusahaan food and beverage yang Terdaftar di Bursa Efek Indonesia Tahun 2014-2016)". Skripsi Tidak Dipublikasikan. Universitas Mercu Buana Yogyakarta. Yogyakarta.

Oktarina, Eka. (2017). "Analisis Prediksi Kebangkrutan Dengan Metode Altman Z-Score Pada PT. BRI Syariah”. Skripi Tidak Dipublikasikan. Universitas Islam Negeri Raden Fatah Palembang. Sumatera Selatan.

Rahmawan, Aditya Rofi. (2015). "Analisis Potensi Kebangkrutan Pada PT. Bank Negara Indonesia Tbk Dengan Menggunakan Metode Altman Z Score". Skripi. Fakultas Ekonomi dan Bisnis Universitas Muhammadiyah Surakarta.

Riyanto, Bambang. (2015). Dasar-Dasar Pembelanjaan Perusahaan. Edisi 4. Yogyakarta. BPFE-Yogyakarta.

Sari, Yuli Ratna. (2016). "Analisis Laporan Keuangan Dengan Mengunakan Metode Altman Z-Score Dalam Memprediksi Kebangkrutan". Artikel Ilmiah. Sekolah Tinggi Ilmu Ekonomi Perbanas, Surabaya.

Sugiyono. (2017). Metode Peneitian Kuantitatif, Kualitatif dan $R \& D$. Bandung: Alfabeta

Utari, Purwanti dan Prawironegoro. (2014). Manajemen Keuangan, Kajian Praktik dan Teori dalam Mengelola Keuangan Organisasi Perusahaan, Edisi Revisi. Jakarta: Mitra Wacana Media.

Wiagustini, Ni Luh Putu. (2014). Manajemen Keuangan. Denpasar: Udayana Universisty Press. 